\title{
The Challenge of Fundraising in Universities in Europe
}

\author{
Carmen Pérez-Esparrells \\ Facultad de Ciencias Económicas y Empresariales, Universidad Autónoma de Madrid \\ Ciudad universitaria de Cantoblanco. Ctra. de Colmenar Viejo, Km. 13 \\ C.P: 28049, Madrid, España, Spain \\ Tel: 34-91-497-4739 E-mail: carmen.perez@uam.es
}

Eva M. Torre

Facultad de Ciencias Económicas y Empresariales, Universidad Autónoma de Madrid

Ciudad universitaria de Cantoblanco. Ctra. de Colmenar Viejo, Km. 13

C.P: 28049, Madrid, España, Spain

Tel: 34-91-497-6759Ｅ-mail: eva.torre@uam.es

\author{
Received: June 14, 2012 \\ Accepted: July 10, 2012 \\ Online Published: July 10, 2012 \\ doi:10.5430/ijhe.v1n2p55 \\ URL: http://dx.doi.org/10.5430/ijhe.v1n2p55
}

\begin{abstract}
The current financial context constitutes a challenge to European Higher Education Institutions in the sense that they must look to increasing their budgets with new activities. This context has led governments and European universities to promote not only the traditional private funding sources (such as transfer of knowledge or tuition fees), but also new means of raising supplementary philanthropic (private) funds for educational and research purposes. Therefore, the actual European context may also represents an opportunity for the development of their fundraising strategy, since a determined fundraising program will bring supplementary private funds to the institutions reducing the frequent internal resistance and increasing the willingness to overcome the lack of experience in this field in Europe.

This paper highlights the change and opportunity that raising independent income from donations implies, in order to achieve excellence and add value to core funding. Here we review UK and Spain cases with special attention in two case studies: Cambridge University, as an example of a well-known prestigious European university with extensive experience in fundraising; and the University of Navarra, as a case of a relevant experience in fundraising policy in a private southern European university.
\end{abstract}

Keywords: Fundraising, Private funding, Funding-state higher education, Governance, Higher education policy/development

\section{Introduction}

Over the past years, in response to the global financial crisis, the funding of European Higher Education Institutions (HEIs) has started on a path of profound transformations of historical dimensions. As a result of the intense reform efforts taken in some countries at the domestic level, in coordination with European policies, university funding is beginning to change, with more emphasis on private streams, which have led many European universities to introduce fundraising strategies. Nevertheless, achieving meaningful progress on fundraising will take time, and the (internal and external) obstacles that universities are encountering in the process are more challenging than originally anticipated.

European HEI sector is tackling the adaptation to the European Higher Education Area (EHEA, called in Europe Bologna Process) and the European Research Area (ERA). These new processes have implied the implementation of new methodologies in teaching activities (changing undergraduate and graduate profiles) and a new way of the promotion of world-class research institutions and infrastructures. In this context, the European Higher Education (HE) Systems are undergoing important changes in the 21st century. Meanwhile, HE Sector is conversing in a real "global market" with an increasing international competition, the European core funding (public funding) is dropping 
or "shrinking".

Generally speaking, European society lacks experience in the fundraising field, just the opposite to what is happening in the United States (US), hence most universities in Europe face internal and external difficulties to develop both, a strategy and a structure to fundraise. For their actual and future development, European HE systems need to imitate the tradition of American university fundraising and adapt it to their different situations (tradition, core philosophy and values), in order to raise supplementary funds for the promotion of the requirements for a greater performance, social acknowledgement and international competitiveness (leading to increasing possibilities to raise funds).

In other words, the current European context comprises not only a menace to the HEI sector funding, but also an 'opportunity' to universities as an incentive: to overcome the (internal) resistance and lack of experience in searching for new funding sources; and to promote the required (external) changes to boost the philanthropy culture in European societies.

The aim of this paper is to explore fundraising strategies in European HEIs according to 21st century needs and to provide a general guidance in their initial approach to a fundraising strategy for the enhancement of the universities in Europe. Consequently, this paper briefly reviews the theoretical dimension of university fundraising (considerably unknown within European countries), and analyses the actual statement of fundraising in European HEIs (deepening in the case studies of UK and Spain) together with outstanding European bibliography on recommendations for a first approach of the matter by European universities and governments.

\section{The concept of fundraising applied to European Higher Education Institution}

Although in US the concept of fundraising is well-known, in Europe there is less tradition of this area in its economical and management fields, therefore we include in this paper a brief theoretical approach to the concept.

University fundraising could be defined as the search for philanthropic private funding through seeking individuals or organizations that want to share the goals and results of the organization through financial contributions. It is a supplementary income stream to support a particular objective or the institutional development of the university (that is to say, designated or non-designated) which consists of gifts, grants and, according to Mora and Nugent (1998), cash payments returned as contributions from salaried staff and insurance payments paid by donors. The voluntary giving must be provided to the university and its various institutions (foundation(s), colleges, schools, departments, institutes, alumni organizations, etc.) by alumni, foundations, corporations or other organizations committed to the values, goals and performance of the universities. (Note 1)

The institutional development of the universities is a highly professional sector in the US, less widespread in state (or public) universities in Europe and almost unknown in Mediterranean countries (Italy, Spain, Portugal, Greece, etc.). When the university fundraising is linked to the institutional development, it requires a generic and long-term commitment of the donor in the financial and physical growth of the institution and therefore a broader understanding of the institution and its mission. Hence, institutional development will also encourage further voluntary giving as feedback.

A Task Force report to the Government of the British Ministry of Education in 2004 differentiates five types of gifts:

- Operating funds: the most frequent type of gift to the HEIs. It consists of annual restricted funds, supporting specific goals such as scholarships, grants for research, support for academic staff and purchase of machines and hardware.

- Annual funds: funds solicited by the institution (usually to alumni) on an annual basis. Annual funds are expensive to raise but asking for them helps to build university-alumni relationships, to create the habit of financially supporting their institution and to identify future big donors.

- Endowments: funds given to the university under instructions from the donor to invest them permanently so that the university will dispose (typically) in perpetuity only of the investment gains (interests and appreciation) to support a project (usually elected by the donor). Endowments are the most difficult gifts to raise because the donor must be engaged not only with the long-term goals of the university, but also must trust in the institution's investment management ability.

- Facilities support: gifts for capital purposes typically given in support of specific building projects.

- Legacy gifts: since its transfer date to the university is unknown, bequests are typically given for very general purposes. 
In this paper we propose a compilation of the two different classifications of the most important European reports about this field (Table 1).

The resources and the experience needed to raise funds vary depending on the kind of funds targeted and the fundraising model. Any initial fundraising strategy must be aware that for most institutions the main fundraising income stream is voluntary giving. Nevertheless, a fundraising strategy of the inexperienced European universities must state the timing and the resources dedicated to each model and type of funds, ensuring in the long term the eventual development of all these models and the building of the capacity of raising all these types of funds.

\section{Fundraising for Higher Education in Europe}

It is in US where the fundraising sector is strongly developed. Nevertheless, the European HE Systems have been built based on a different "philosophy", which is what prevents European HEIs from achieving the university fundraising performance of the HEIs in the US. Therefore, we hold the view that, despite good practices can be drawn from the US' HE Systems in the university fundraising field, European HEIs should work to enhance their fundraising strategies and structures, but not to achieve the fundraising performance of the US institutions, in order to respect and preserve its 'welfare philosophy'.

Thus, we hold the view that by boosting European universities' prestige, we should always bear in mind all three university missions in order to preserve the characteristics of the European Welfare Economy in the HE sector, and that since the public funding needs to be complemented with private funding to cover the cost of excellence, university fundraising is essential to provide the needed supplementary funds. In this regard, some European countries have also established schemes aiming at similar goals for the enhancement of excellence, such as the following ones: a new "university Challenge" (DIUS, 2008) and Strategic Development Fund (SDF) (2010-11) in UK; Pôles de Recherche et d'enseignement Supérieur (2006) and Programme Campus (2008) in France; Initiative for excellence (2006-2012) in Germany; and Campus de Excelencia Internacional in Spain. These experiences have provided an opportunity to diversify private income streams.

In this context, European universities face an environment characterized by (Agasisti et al., 2012): (i) a trend of decreasing importance of public funding (state core funding) in relation to the total amount of universities' resources, (ii) public funding models based on performance indicators; (iii) greater autonomy of universities in academic and management aspects; (iv) and a higher level of accountability. Furthermore, we would like to add to this description of the European HE context that the state core funding is frequently related to governments' priorities, which can be different from those of the universities.

In addition, the decreasing trend of the state core funding, which represents approximately $80 \%$ of European universities total financial resources according to Education at a Glance (2011) and 72.8\% according to Financially Sustainable Universities II (2011), has been sped up as a consequence of the current economic crisis. Therefore, European HEIs are in a critical situation in terms of global competition, but they also stand before the opportunity of an urging environment for the development and implementation of a fundraising strategy that will provide funds for educational and research purposes, and therefore will enhance excellence, leading to increasing possibilities to raise funds.

The data published by the EUA (2011) with the results of the online questionnaire as the main source reveal the gradual progress of private funding in the European universities in terms of students contributions $(9.1 \%$ of total funding), funding coming from contracts with business sector $(6.5 \%)$, the philanthropic funding (4.5\%) and service-related income (4.1\%); four variables which show a growing trend in many European universities.

European HE Systems are immersed in societies where a philanthropy culture is not as strongly developed and settled as in the US, therefore European universities have generally not developed efficient systems for raising funds and have not seriously sought voluntary support so far (except a few particular cases); but also European Governments have not decidedly encouraged the HEIs to seek voluntary gifts, nor asked citizens for voluntary and financial support for public universities.

In other words, it can be claimed that, the current general low performance of the university fundraising and the general lack of attempts to promote it through public policies and fiscal systems, are a direct consequence of this lack of philanthropy culture in Europe, especially in the educational and research fields. However, some exceptions can be found mainly among prestigious, private or religious universities, from which we have selected our study cases.

Nevertheless, Europe is becoming increasingly aware of the high potential of development of the university fundraising field and its prospective benefits for HEIs. Consequently, a number of initiatives to study and promote this supplementary income stream have been carried out recently. First of all, it is worthy to highlight the efforts of 
the Council for Advancement and Support of Education (CASE) to promote university fundraising by offering bibliography and advice about best practices and the implementation of the different dimensions of the fundraising. Secondly, it is also important the Transnational Giving Europe (TGE) which allows donors who are taxpayers in one of the 15 countries affiliated to TGE, to donate to foreign institutions from countries also belonging to TGE, without sacrificing the tax benefits in their country of tax contribution. (Note 2)

In 1998, Mora and Nugent stated eight difficulties for the enlargement of fundraising in Europe, which we consider that nowadays, are still present. The difficulties defined by these authors were the following:

1. Lack of tax incentives. In some countries, the laws do not concede to the universities the liberty to maintain their own property. Donations in these cases would be converted into gifts to the State and not to the institution.

2. The philanthropic spirit is much less pronounced in Europe than in the US.

3. Lack of differentiation among universities. Most European universities do not make great efforts to distinguish themselves from each other.

4. Institutions are not encouraged to identify their students with their own university. European universities do not treat students as clients to the same extent as those in the US.

5. Little attention to their graduates and alumni, who are a key part of the philanthropic process.

6. Lack of institutional fundraising and development offices.

7. Academic distrust towards business and industry and to providing services to society in general.

8. Lack of organised university sports.

Despite these circumstances, exceptionally, philanthropy (voluntary supports) can be a substantial source of funding for universities as proved by The United Kingdom and Sweden, where it funds more than $16 \%$ of university R\&D expenditure. Nevertheless, its potential has not been fully realised in Europe, as shown in the abovementioned European average in philanthropy funding (4.5\%) (EUA, 2011).

Most of the European universities try to leverage funds from philanthropic sources (foundations, trusts, charities, non-profit organisations, corporate and individual donors, alumni) but with mixed results. Disappointing results are often due to a lack of a strategic approach (fundraising is not considered as part of the universities' funding strategy) and a lack of a professional unit of fundraising or a Development office, mainly in the Mediterranean countries (France, Italy, Spain, Portugal, Greece, etc.). Moreover, peer learning is difficult given the lack of reliable data on university fundraising in Europe, as well as the huge diversity of legal, institutional, historical, cultural and economic contexts in European countries. This is why we have selected two European countries, one of them with traditions and experience in university fundraising, and the other one with less tradition in this issue (except for private and religious universities, such as the selected case study for Spain).

\subsection{The case of United Kingdom and the Cambridge University fundraising policy as a good practice}

We chose as a case study the program developed in the UK to encourage private fundraising by universities, for being an Anglo-Saxon country with a culture halfway between US and Europe. In the UK, only the most prestigious universities (such as Cambridge, Oxford, Imperial, University College London, Edinburgh, etc.) present a developed fundraising system. In order to foster the fundraising activity of less known universities, the Department of Education in UK created in 2004 a Task Force for "Increasing voluntary giving to higher education" that analysed the situation and proposed eleven recommendations (directed to universities, national institutions on the HE sector and UK Government) that can be extrapolated to the rest of the European HE Systems after their adaptation to a specific country naturally.

This report stresses the importance of university-alumni/other stakeholders relations, being crucial to enhance donor's proactive identification and to work on the study of their characteristics, in order to strengthen their relationship with the university and to increase the effectiveness of the measures taken to encourage the university fundraising.

In the case of British universities, they should establish a professional unit of fundraising and integrate the fundraising strategy in the institutional leadership law, in order to strengthen the abovementioned university relations. In achieving these goals, national institutions in the HE sector (such us the Committee of University Chairmen -CUC-, Universities UK -UUK- and the Standing Committee of Principals -SCOP-) must collaborate, and senior training must be tackled. 
On the other hand, the British government is a key role in promoting university fundraising, being responsible for simplifying the actual tax-relief system, for introducing wider tax incentives to voluntary giving and for considering new typologies of voluntary giving.

This report also recommended the government to establish a matched funding scheme to support institutions' capacity building for effective fundraising, encouraging private contributions by supplementing them with public funds. As a result of this last recommendation England established a Matched Funding Scheme for Voluntary Giving 2008-2011 endowed with £200 million which was completed in July 2011, and in 2009/2010 Wales had established its 3 year Matched Funding Scheme with $£ 10$ million which is still operating.

In order to reinforce the development of a fundraising strategy in non-experienced universities, both schemes supplement each pound raised by less experienced universities in the fundraising field with another $£ 1$ (in the ratio 1:1 private public); in the ratio 2:1 private public for universities that already count with a development program; and in the ratio 3:1 private public for universities with an already important experience in the university fundraising field. Furthermore, with the purpose of ensuring supplementary public funds for every HEI participant, the amount available to institutions was capped.

In order to assure their effectiveness and efficiency, both schemes are complemented by a number of services and obligations, of which we would like to highlight:

1. The training and support programme for the Education Institutions participating in the form of scholarships to training events.

2. The Matched Funding Online Resource Centre, that provides the scheme participants with on-line useful information about fundraising.

3. The Matched Funding Awards (organized only by the English scheme) and the CASE Europe Matched Funding Volunteer award, awarded to universities because of their fundraising performance and to an individual because of its contribution in the university fundraising field, respectively.

4. The requirement to the institutions participating to provide information about its fundraising performance to Ross CASE, through the participation in the Ross CASE Survey, which will enable analysis of the results achieved through the schemes. (Note 3)

Since the Matched Funding Scheme for Voluntary Giving 2008-2011 was completed on July 2011, the Ross Case Survey 2010-11 (2012) provides an overall view of the scheme's results.

- The protection of the university fundraising sector from the effects of the economic recession provided by the scheme in terms of sustaining growth of the philanthropic support to HE indicators.

- An "acceleration of some of the patterns of growth that had been present in the years leading up to the matched funding scheme" (page 75).

- "A culture change about philanthropy across HE", which has resulted in a wider range of HEIs willing to 'ask' for support and successful in fundraising, and universities' greater investment in these strategies (page 75).

- "A significant impact in changing donor behaviour", which has resulted in an increasing number of donors (page 34).

Below, we study the University of Cambridge as a case study of good practices in fundraising in the United Kingdom. The University of Cambridge consists of a "holding" comprising: the university institution (University of Cambridge), 31 colleges, the Cambridge Alumni Relations Office (CARO), the alumni office of each one of the 31 colleges, the alumni organisation Cambridge in America, 419 alumni groups throughout 101 countries, and other institutions (e.g. museums, collections, libraries) and foundations (http://www.cam.ac.uk/, 2012 and Alumni World Wide Directory 2011 - 2012).

The base line of the University of Cambridge is very different from that of any average European university: firstly, because of its international nature; secondly, because of its position in the international rankings and its international-renowned nature and prestige; thirdly, because it is located in one of the European countries with a better developed philanthropic culture (as shown by the fiscal benefits for voluntary gifts, the existing large scale fundraising campaigns, the public information available about the donation process, and the current national campaigns for the promotion of voluntary giving); fourthly because of its wide experience in the fundraising field (as revealed by the strength of the relations of the University with its stakeholders, alumni and students, and the figures 
of funds raised reached); and finally, because of its size.

Therefore, the good practices drawn from this case study must be carefully treated and adapted before being applied to any particular university, especially in the case of state universities in Europe, given that Cambridge is a private university.

This university has opted for its differentiation through the communication of a solid "brand name and image" associated with quality, innovation, independence, excellence and international recognition: every internal and external communication of the University and any project launched are consistent with that "brand image". Such differentiation has led the University to an important internal and external diversity of its activities. (Note 4)

The comprehensive communication strategy of the University of Cambridge involves a key factor for the university fundraising performance, in the sense that it not only transmits the importance of the contribution of the University to the fulfillment of the needs of society, its role in the way out of the current economical crisis (through the transfer of knowledge), and its commitment to excellence; but it also emphasised the priority lines of action of the University, which is essential in order to obtain the highest possible additional funding for them. It is important also to highlight that it has been during the economical crisis when the University of Cambridge has invested more heavily in its fundraising strategy.

Furthermore, and still regarding its communication strategy, the University of Cambridge launched in 2001 (publicly in 2005) its $800^{\text {th }}$ Anniversary Campaign, a large scale philanthropic fundraising campaign whose goal, to raise $£ 1$ billion by 2012 (not including legacies not taken in), was reached in 2010 despite the economic crisis, becoming the first non-American university in raising over $£ 1,000$ million in a single campaign to attract philanthropic funds.

The slogan of the Campaign, "Celebrating the past, transforming the future" summarizes the outstanding international performance of the University so far, and the long term commitment of the University of Cambridge to maintain the continuity of both the international excellence and the valorization of knowledge transfer to society. As well as the University's funding and fundraising strategy, the $800^{\text {th }}$ Anniversary Campaign was led by the university leaders and all the spheres of the institution took part in the promotion of the Campaign.

In regard to the funding of the University, we consider a good practice the fact that it comprises the fundraising strategy as an important part of the university funding, being led by the leaders of the University and promoted from faculties, schools, colleges, departments, institutes, associations, foundations, and other university institutions. However, the University of Cambridge not only promotes economical (quantitative) collaboration from its stakeholders, but also qualitative collaboration (e.g. counseling and volunteering).

The University of Cambridge counts on a professionalized Development Office (Cambridge University Development Office - CUDO) which reports to the leaders of the funding strategy, that is to say, to the governing bodies of the University. It is also worthy to note that, among its functions, CUDO also works to answer any question about the donation process that could arise, and provides donors with counseling about their gifts. Furthermore, this information is complemented with comprehensive and clear information about how to make a donation, the different typologies of donations accepted, the advantages for the donor and for the University related to each kind of gift, the various ways to give (online, by phone, etc.), the purposes supported through voluntary giving, etc.; making it as easy and desirable as possible to make any donation to the University.

The philanthropic funds received by the University of Cambridge are restricted (to specific projects or purposes) or unrestricted (being used on a discretionary basis by the University) giving support to: the best students, through the University of Cambridge grants scheme; the required elements to attract outstanding academics in order to maintain the University's international leadership in teaching and research; innovative research ideas, research centers and researchers in order to ensure the independence of the University; and maintenance of the University's collections and heritage.

Regarding public recognition of gifts, the University provides several means to publicly acknowledge the different types of donors and sponsors, in addition to the communication of the positive impact of philanthropic funds in the best performance of the University, regardless of the amount of the donation.

The specific characteristics of the University of Cambridge and the good practices exposed applied have led the institution to:

- High alumni participation in the "university life".

- $\quad$ Some of the donations to the University of Cambridge reach several million pounds. 
- The university counts on committed large traditional donors: donors (and even families of donors) who have long donated large sums of money to the University of Cambridge.

- Important amounts of international gifts, receiving a relatively huge quantity of philanthropic funds from donors of Anglo-Saxon countries.

\subsection{The Spanish case and the University of Navarra as a case study of fundraising good practices in Spain}

With the purpose of contrasting the UK case study, we now focus on the state of the art of fundraising in Spain as a representative example of the historical and cultural background in European southern Mediterranean countries, which results in an important fundraising lag.

In the Spanish case, it can be said that the low activity related to the transfer of knowledge (about $5 \%$ of university budgets in 2008 according to the report Universidad en Cifras, 2010) represents clearly insufficient collaboration of the Spanish companies with the public R\&D, even though it has improved in the last decade. Moreover, if within this $5 \%$ we focus solely on philanthropic funding, it can be stated that university fundraising in Spain represents insignificant funds that are not clearly identified in the financial statements of HEIs. Furthermore, Spain does not count on any data base about university fundraising performance, which certainly makes it very difficult to study the university fundraising field.

One of the causes of this university fundraising situation, besides the above-mentioned low university-business collaboration, is the scarce legislation (including fiscal incentives) and public initiatives in promoting voluntary giving, and particularly voluntary giving to HEIs.

The Spanish Ministry of Education has seriously considered issues related to the financing of public universities, as demonstrated by the several reports on university funding policy that have been published lately; however, those reports do not make any explicit reference to fundraising.

The Spanish HE system is prevailingly homogeneous, making it necessary to promote differentiation and diversification among Spanish state universities to help HEIs to distinguish themselves from other universities and to define a strategic position in their socio-economic European, national, regional and local context.

Given these premises, the Spanish government established the Campus of International Excellence (CEI) scheme, aiming to promote university-business collaboration, university differentiation, and Spanish HEIs reputation. In other words, the Spanish government does not encourage voluntary giving to universities, but promotes some necessary preconditions for successful university fundraising. Furthermore, for participating universities, the CEI has worked as a communication tool of their purposes, activity and role in solving the needs of society, and enhancing participants' prestige.

Regarding Spanish HEIs, it can be said that state universities have not developed funding strategies which include specific fundraising programs; however, recent isolated cases of Spanish public universities that have announced timid fundraising activities have appeared:

- Universidad Politécnica de Cataluña (UPC), Barcelona Tech is searching technological partners through the Program UPC21 with the purpose of increasing its scientific outputs, transferring its results to society and leading international projects of excellence.

- Universidad Carlos III de Madrid (UC3M) has launched a fundraising campaign among alumni, and the initiative "Friends of the UC3M" directed to alumni and companies. Both campaigns have already raised a certain amount of funds.

Thus, although the vast majority of Spanish universities possess an alumni organization or unit, their functions tend to focus not on fundraising, but on maintaining alumni linked to the university through socio-cultural and academic activities. Alumni organizations in Spain should exploit these (qualitative) characteristics and become the agent that reaches all students of the university, and therefore asks them periodically for small donations (annual giving) to (quantitatively) support the long term purposes of the institution, as well as identifying prospective major donors among them for the future, becoming the seed of a future "fundraising unit" of the university.

Within the Spanish public universities, the university Foundation (some universities have more than one foundation) holds the know-how about university-business collaboration for R\&D and lifelong learning, being important for Spanish HEIs to work on a greater interaction and knowledge sharing with their foundations, that is to say: 
- Ensuring integration and consistency of the communication strategies of the University, its Foundation(s) and the rest of the university institutions (among others, the Social Council or Consejo Social) given that those strategies are targeted to different stakeholders.

- Sharing databases of the University, its Foundation(s) and the rest of the university institutions, so that prospective major donors and partners (individuals or organizations) can be identified.

- Assessing donations through (one of) the Foundation(s) (including giving counseling for donors) so they can qualify for the maximum tax benefits.

- Seeking greater qualitative collaboration from companies related to the Foundation with the universities' activities and purposes, for example by helping in the communication of the fundraising program, by providing facilities for the development of fundraising/training activities, offering internships, etc.

In Spain, within private institutions fundraising is better developed. Among them, it is worthy to highlight the case of some Spanish business schools (IESE, Instituto de Empresa, ESADE), University of Navarra, IE University, etc., which have a highly developed strategy and structure of fundraising and of care for alumni fundraising probably due to their link with business schools. Bellow, we study the University of Navarra as a case study of fundraising good practices in Spain.

The Universidad of Navarra (UNAV) is one of the most prestigious private universities in Spain. It is a very particular case of study because of its link with the Business School IE University (well positioned in international rankings) and its private and religious characteristics, which affects its relation to stakeholders. Nevertheless, this case provides a number of best practices in a country like Spain where universities have less fundraising experience than UK.

The philanthropic funds received by this university (and its various institutions: alumni organizations -of UNAV and IESE- and Friends of Universidad de Navarra Association) are allocated to the following functions:

- Operating functions of the fundraiser institution.

- Strengthening of university-stakeholders relations.

- $\quad$ Lifelong learning programs.

- Grants, scholarships and fellowships: each institutional scheme is directed to a different segment of the university community (bachelor students, graduate students, alumni and faculty), but all of them are funded by philanthropic funds and aim to enhance motivation and academic performance of the whole student body through the recruitment and development of talent. They only help talented individuals who cannot afford the university's tuition fees.

In 2003, the Alumni Organization of the UNAV established the Alumni Scholarship Scheme (Becas Alumni), whereby alumni of the university finance (fully or partially) tuition fees and (if necessary) housing for talented students that otherwise can not afford to study in this university. Since its implementation, donations to the scheme and number of scholarships have shown a positive trend, and in the academic year 2011-2012 it fundraised $€ 1,775,155$ that covered the cost of 266 scholarships.

In order to maximise the benefits of the scheme, scholars receive a comprehensive training, constant student monitoring and constant communication of their duty to correspond to the opportunity provided. Moreover, they participate in specific activities designed to enhance scholars' relations between themselves, and generate a new stakeholder ("lobby") of the UNAV.

An interesting characteristic of this Scheme is its open/direct call for solidarity. Members of the Alumni Organisation receive a compensation for supporting the university (member fees) in the form of different services (lifelong learning, organised activities, etc.), but for those who support the Alumni Scholarship Scheme there are no benefits.

Regarding the Alumni Organisation of UNAV, we must highlight the adaptation of the member benefits offered to the characteristics of those, through a specific recruitment campaign and catalogue of services and activities created, for example for current students and alumni, as well as differentiated member fees.

There is a number of common characteristics in the fundraising activity conducted by the alumni organisations (of UNAV and IESE) and Friends of Universidad de Navarra Association; and the various institutions of the University of Cambridge:

- A key differentiation factor of the university from other domestic HEIs is their intrinsic culture, which is present in all areas of activity undertaken by them. 
- The whole university community participates in the communication of this inherent culture. There is even an organization chart of persons responsible for instilling the culture of the university in the different segments of the university community.

- The International nature of the University, which in the Spanish case comprises English and Spanish communication because of its relation with the Latin America region.

- Professionalization of the fundraising function and establishment of a unit of fundraising or a Development office.

- Commitment of a private university with the needs of society and university excellence.

- Establishment of a large scale fundraising campaign: which are directed to "people from all walks of life" which, in practice are usually students, alumni and their families but these fundraising campaigns also aimed at the "friends" of the university.

- Strong communication of: university (or/and fundraiser institution) purposes, main action lines (e.g. every activity or publication mention the Alumni Scholarship Scheme) and results/benefits for the university/society achieved thanks to donations.

- Public acknowledgement of donors by segments.

- Accountability of institutions and initiatives funded through philanthropic funds.

- Donor's information and advice service.

- Strong interaction from university and its university colleges and encouragement of establishment of relations between themselves for alumni, and also for current students. Both lines of action will strengthen university-stakeholders relations.

- Commitment and participation of institutional leaders in the university fundraising institutions and their programs, schemes and activities.

- Consistency between the intrinsic culture and values of the university and all activities undertaken by itself and its various institutions.

- Allocation of gifts through a Foundation of the university in order to make contributions eligible for as many tax reliefs and exemptions as possible. In the case of the UNAV, the foundation is even formally committed (agreement sign in 2009) to helping in fundraising for a number of specific goals: new research centres, a museum and a post-graduate building adapted to EHEA.

\section{Conclusions}

As a result of the current financial pressures, all the European University System has to be made more competitive and entrepreneurial. Structural changes need to occur, not only in public funding issues due to the economic crisis, but also in private funding matters, such as university fundraising. In this sense, fundraising can be converted into a mechanism for the introduction of modernity and competitiveness in the European HE sector.

Regarding the public funding changes that are needed, the core funding of universities (block grants) has to be increasingly allocated by a performance-based approach, the combination of performance contracts and formulas has to be reinforced and independent funding schemes for teaching and research have to be established.

With regard to university private funding issues, the challenge for universities remains in establishing higher tuition fees in some programs or services and in the valorization of the transfer of knowledge; furthermore, it also remains in to developing a fundraising strategy and structure.

These changes are the broader basis for European universities to "move away" of the power and influence of Governments and to increase university transparency, help easy communication of HE financial needs, enhance efficiency and effectiveness.

Once these changes are addressed, as a consequence of the greater university autonomy in Europe and the coming progress on the university fundraising field, prestigious European university leaders would largely expect to get more funds in the coming years from alumni, charities foundations and other potential donors as in the American case.

Focusing on the fundraising issue, we hold the view that European governments and universities must work together in two ways. On the one hand, governments should improve public policies to promote fundraising from philanthropic sources, that is to say, to develop a culture of "giving" through fiscal incentives, match funding schemes, awareness campaigns and communication of the university's social role (outreach or community service); 
and, on another hand, European HEIs must introduce the culture of "asking" through strategic leadership and professionalism of the fundraising function with a Development Office, focused on building and preserving student and alumni loyalty and building an atmosphere of trust towards the university management among their stakeholders.

European state universities are bound to develop a fundraising strategy in order to enhance their performance, increase their reputation and prestige and strengthen the commitment of more stakeholders with their university. Despite the "opportunity" that the actual context provides in terms of overcoming the internal resistance to a fundraising activity within the state universities, each HEI must plan carefully their steps depending on the kind of funds and donors targeted, studying the subject before setting the goals, the timing and the resources of their fundraising activity, asking also for professional advice when required and bearing always a medium or long-term view.

However, in the case of inexperienced universities from European countries where governments do not encourage voluntary giving for educational and research purposes, in our opinion, it may be wiser to be cautious and focus on initial initiatives that will develop the necessary conditions for a successful fundraising program (such as reinforcing alumni organisations or increasing collaboration with external stakeholders specially within their geographical area of influence) in order to be ready when the financial and economic context improves.

\section{References}

Agasisti, T., Pérez-Esparrells, C., Catalano, G. \& Morales, S. (2012). Is expenditure on higher education converging across EU-15 countries? Studies in Higher Education 37:2. 235-252. http://dx.doi.org/10.1080/03075079.2010.506952

Alumni Navarrenses, Universidad de Navarra. (2003). Folleto Alumni, Ed. KEN Agencia de Comunicación. [Online] Available: http://www.unav.es/alumni/acerca/folletoalumni.pdf (June 25, 2012).

Alumni Navarrenses, Universidad de Navarra. (2003). ¿Qué fue para ti la Universidad?. Navarra. [Online] Available: www.unav.es/alumni/estudiantes/presentacionBAN.pdf (June, 25 2012).

Browne Report. (2010). Securing a Sustainable future for higher education. An Independent Review of Higher Education Funding \& Student Finance. UK. [Online] Available: http://www.bis.gov.uk/assets/biscore/corporate/docs/s/10-1208-securing-sustainable-higher-education-browne-report. pdf (June, 25 2012).

CAE, (various years). Voluntary Support for Education Survey. Council for Aid to Education. [Online] Available: www.cae.org

Cambridge University Alumni Relations Office. (2012). Alumni World Wide Directory 2011 - 2012. University of Cambridge. [Online] Available: http://www.alumni.cam.ac.uk/groups/AWD_2011_web.pdf (June 25, 2012)

Casani, F., Pérez-Esparrells, C. \& Rodríguez-Pomeda, J. (2010). Nuevas estrategias económicas en la universidad desde la responsabilidad social, Revista Calidad en la Educación. 33, december. 255-273. Santiago de Chile: Consejo Nacional de Educación.

CRUE. (various years). La Universidad Española en cifras. Información productiva y financiera de las Universidades públicas Españolas. Indicadores universitarios, Madrid: Observatorio universitario, CRUE.

European Commission COM. (2011). 567 final. Supporting growth and jobs - an agenda for the modernisation of Europe's higher education systems. Available: $\mathrm{http} / / /$ ec.europa.eu/education/higher-education/doc/com0911_en.pdf

European Comission. (2007). Engaging philanthropy for university research. [Online] Available: http://ec.europa.eu/invest-in-research/pdf/download_en/rapport2007_final.pdf (June 25, 2012).

European Commission COM. (2006). 208 final. Delivering on the modernisation agenda for universities: education, research and innovation. [Online] Available: http://ec.europa.eu/education/higher-education/doc1324_en.htm (June $25,2012)$.

(June 25, 2012).

European University Association. (2011). Financially Sustainable Universities II, European universities diversifying income streams. Brussels. [Online] Available: http://www.eua.be/Pubs/Financially_Sustainable_Universities_II.pdf (June 25, 2012)

Mora, J-G., Nugent, M. (1998). Seeking new resources for European universities: the example of fundraising in the 
U.S., European Journal of Education. 33. 1.

OECD. (various years). Education at a Glance. OECD Indicators. Paris. [Online] Available: http://www.oecd.org/document/2/0,3746,en_2649_39263238_48634114_1_1_1_1,00.html (June 25, 2012).

OECD. (2011). Highlights from Education at a Glance 2011. Paris. [Online] Available: http://www.oecd.org/document/2/0,3746,en_2649_39263238_48634114_1_1_1_1,00.html (June 25, 2012). http://dx.doi.org/10.1787/eag_highlights-2011-en

Ross CASE. (various years). Ross-CASE Survey.

Task Force report to government. (2004). Increasing voluntary giving to higher education. UK: Department for Education and Skills. [Online] Available: http://www.bis.gov.uk/assets/biscore/corporate/migratedd/publications/i/increasingvoluntarygivingreport.pdf (June $25,2012)$.

\section{Notes}

Note 1. American universities understand institutional development as "institutional advancement", that is to say, as a systematic, integrated method of managing relationships in order to increase an institution's support from its key stakeholders. It comprises communication and marketing, alumni relations and development (Task Force report, 2004).

Note 2. The 15 countries affiliated to TGE are the following ones: Belgium, Bulgaria, France, Germany, Hungary, Ireland, Italy, Luxembourg, the Netherlands, Poland, Romania, Slovakia, Slovenia, Switzerland and the UK.

Note 3. "CASE is the membership association that serves educational institutions around the world by enhancing the effectiveness of their fundraising, alumni relations, communications and marketing professionals - the group of related disciplines to which North Americans give the shorthand term "institutional advancement" (Ross CASE Survey 2007-2008, p. 1). Ross CASE stands for the collaboration between the British branch of the international association CASE and the Ross Group. As a result of the first recommendation of the Task Force report (2004), Ross CASE has been producing since 2001 - 2002, annual reports (carried out annually by the National Centre for Social Research -NatCen- on their behalf) that provide an overview of fundraising and its cost in universities and other educational institutions in UK. It represents the only source of data about the subject and performs an aggregate analysis (does not specify the data regarding each university), allowing the study of trends and evolution of university fundraising (which seems to be positive despite the current economic crisis situation), supplemented with the opportunity given to participating institutions to benchmark themselves against aggregated data of their own selection of at least six peer HEIs (in order to preserve data confidentiality).

Note 4. A clear example of this consistency between the "brand image" of the University of Cambridge and its activities is provided by the characteristics conferred to the merchandising line for alumni: high quality of their services and products, "ethic" nature and participatory environment in the definition of the products offered. 
Table 1. Models of interaction university-donors and its techniques

\begin{tabular}{|c|c|c|c|}
\hline $\begin{array}{l}\text { Interaction } \\
\text { model }\end{array}$ & $\begin{array}{l}\text { Source of } \\
\text { funds }\end{array}$ & Characteristics & Techniques \\
\hline $\begin{array}{l}\text { 'Alumni' } \\
\text { model }\end{array}$ & $\begin{array}{l}\text { Alumni and } \\
\text { university } \\
\text { "friends" }\end{array}$ & $\begin{array}{l}\text { Continuous collection of small donations } \\
\text { from a large pool of donors. } \\
\text { - University actors: alumni relations } \\
\text { offices or fundraising units. } \\
\text { - Kind of gifts: voluntary giving } \\
\text { typically of non-designated funds. } \\
\text { - Donors' criteria: personal interests } \\
\text { and wishes. } \\
\text { - Interaction with potential donors: } \\
\text { structured but informal. }\end{array}$ & $\begin{array}{l}\text { - Annual Giving: telephone } \\
\text { campaign; direct mail (mass } \\
\text { mailings of standard letters, } \\
\text { e-mails). } \\
\text { - Events and services to build } \\
\text { loyalty: social events for segments } \\
\text { of alumni, services and discounts } \\
\text { for alumni. } \\
\text { - Recognition of gifts and } \\
\text { actions in favor of the university: } \\
\text { newsletters. }\end{array}$ \\
\hline $\begin{array}{l}\text { 'Major Gift' } \\
\text { model }\end{array}$ & $\begin{array}{l}\text { Major } \\
\text { Donors: } \\
\text { alumni and } \\
\text { other } \\
\text { wealthy } \\
\text { individuals }\end{array}$ & $\begin{array}{l}\text { This model is the most common in many } \\
\text { universities. } \\
\text { - University actors: university leaders. } \\
\text { - Kind of gifts: large donations directed } \\
\text { to highly specified purposes (by donors) in } \\
\text { line with the university's strategy. } \\
\text { - Interaction with potential donors: } \\
\text { development of personal relations. }\end{array}$ & $\begin{array}{l}\text { - Prospect management system } \\
\text { to identify and nurture potential } \\
\text { major donors. } \\
\text { - Personal visits: senior level. } \\
\text { - Legacy campaigns. } \\
\text { - Recognition: donor names on } \\
\text { buildings, lists of supporters. } \\
\text { - Fellowships } \\
\text { professorships }\end{array}$ \\
\hline $\begin{array}{l}\text { 'Foundation } \\
\text { Research' } \\
\text { model }\end{array}$ & $\begin{array}{l}\text { Research } \\
\text { Foundations }\end{array}$ & $\begin{array}{l}\text { Researchers' seeking funds activity. } \\
\text { - University actors: individual } \\
\text { researchers and professors. } \\
\text { - Kind of gifts: grants from (public and } \\
\text { private, big and small) research funding } \\
\text { bodies. } \\
\text { - Donors' criteria: foundation's aims. } \\
\text { - Interaction with potential donors: } \\
\text { highly formal and structured through } \\
\text { application rules of procedure and } \\
\text { selection criteria. }\end{array}$ & \begin{tabular}{lll}
- & \multicolumn{2}{c}{ Target identified. } \\
- & Well prepared research \\
projects. & & \\
\end{tabular} \\
\hline $\begin{array}{l}\text { 'Corporation' } \\
\text { model }\end{array}$ & $\begin{array}{l}\text { Corporations } \\
\text { and } \\
\text { Foundations }\end{array}$ & $\begin{array}{l}\text { Major Corporations and Foundations that } \\
\text { share university purposes. } \\
-\quad \text { University actors: university offices } \\
\text { and leaders. } \\
\text { - Kind of gifts: philanthropic funds of a } \\
\text { more general nature. } \\
\text { - Donors' criteria: organization's aims. } \\
\text { - Interaction with potential donors: } \\
\text { structured approach and personal } \\
\text { relationships building. }\end{array}$ & $\begin{array}{ll}- & \text { Target identified. } \\
- & \text { Well prepared business cases. } \\
- & \text { Sponsorship opportunities. } \\
- & \text { Recognition: donor names on } \\
\text { buildings, lists of supporters. } \\
\text { - } \quad \text { Fellowships } \\
\text { professorships }\end{array}$ \\
\hline $\begin{array}{l}\text { 'Multi-mode' } \\
\text { model }\end{array}$ & & $\begin{array}{l}\text { Medley of the 'Foundation Research' } \\
\text { model and the 'Corporation' model, with } \\
\text { many different options available for } \\
\text { universities to choose from. }\end{array}$ & \\
\hline
\end{tabular}

Source: Personal compilation based on Increasing voluntary giving to higher education. Task Force report to Government (2004), p. 63; Engaging Philanthropy for University Research. Report by an Expert Group on Fundraising by universities from philanthropic sources: Developing partnerships between universities and private donors (2007) p. 10, 11. 